\title{
Temperature Measurement of Nine Phase Induction Motor Drive Without Load and Various Load Conditions
}

\author{
Dr. Manjesh \\ Associate Professor: \\ Dept of Electronics Science \\ Bangalore University \\ Bangalore, India
}

\author{
Nilima S. Dabhade \\ Research Scholar: \\ Dept of Electronics Science \\ Bangalore University \\ Bangalore, India
}

\begin{abstract}
Research and Development $(\mathrm{R} \& D)$ in recent days towards the power electronic system and Motor Drives Concentrate their attention on Multi-phase motor drive systems, due to some inherent advantages over three-phase motor drives like high torque density, efficiency, heavy loads etc. Since variable speed of $\mathrm{AC}$ power drives need converters for $\mathrm{AC}$ to $\mathrm{DC}$ power supply the number of phases can be change very easily, this led to increase the interest of multiphase drive applications in the field of Agriculture, aircraft, Electronics Vehicles etc. Almost all loads Have nonlinear characteristics which exhibits heat at parts of the loads. When load is subjected to high current density cause equipment failure hence presented work focus on the Experimental analysis of Temperature measurement at various body parts of Nine Phase Induction Motor with No load and load condition using PWM drive. Data Analysis has been done to monitor temperature effect on stator, rotor and other parts of the motor by interfacing temperature module kit with laptop monitor screen using $\mathbf{J}$ type thermocouples.
\end{abstract}

Keywords-Nine phase Induction Motor, Nine phase Inverter, PWM, Microcontroller kit, Temperature Modul kit, Power Analyzer.

\section{INTRODUCTION}

Multi-phase motor drives gather more attention in recent years due to advantages over three phase drives. Since variable speed of AC power drives need converters for AC to DC power supply the number of phases can be change very easily, this led to increase the interest of multiphase drive applications. The advantages of multiphase over three phase motor drives are current and voltage harmonics, high torque density, cost reduction etc. Multiphase drives have major applications in high torque motor drives like, Agriculture, aircraft, hybrid electric vehicles, etc.

Most of the failures in induction motors are originates from the thermal reactions at various parts of the motor. This overheating at major parts like stator, rotor, bearing, shaft, and frame causes the failure due to thermal stress. Breakdown of stator winding insulation due to thermal stress is of the major cause of motor failure hence, prevention of such failures is the major task. The thermal effect and losses on various parts of the motor can be reduced by implementing various modulating techniques.

Inverters are the power converters which convert DC supply to AC output supply for desire phases. The topology of multiphase inverters uses number of semiconductor devices (MOSFET's/IGBT's) with respect to number of phases.
Switching singles are fed to switching devices trough control generators.

In PWM inverters, gate of semiconductor device is controlled by PWM control signals. The Pulse Width Modulation (PWM) technique is implemented by switching of modulated pulses with constant amplitude and variable pulse width or duty cycle. PWM technique can be extended with switching signals of square, sinusoidal or sawtooth signals depends on modulation technique. The presence of harmonics depends on selection of modulation index. Harmonics can be reduced by making modulation index to unity. Fig.1. shows the PWM control signal generated by microcontroller, the output load voltage and current can be changed by varying width of the pulses, also frequency of the two signals is nearly made equal [1-7].

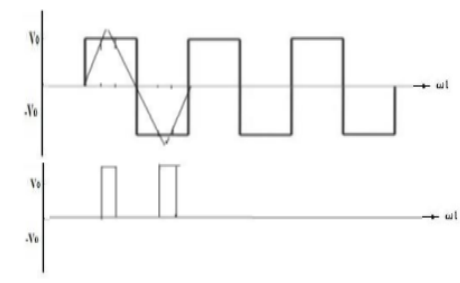

Fig.1. PWM signal generation

The presented work focused on the temperature measurement of nine phase induction motor at various parts without and with various load. Generation of PWM Control signals through the microcontroller 8051. Graphical analysis of experimental data monitored with power analyzer and temperature module kit.

\section{TOPOLOGY OF NINE PHASE INDUCTION MOTOR}

Multiphase motor drives constructed with $\mathrm{N}$ number of phases where stator windings are displaced by ' $360 / \mathrm{N}$ ' phase. As illustrated in Fig.2. The nine stator windings (Vas-Vis) of an induction motor has displaced by $(360 / 9) 40^{\circ}$ phase shift with each other fed by nine legs and eighteen switches of voltage source inverter (VSI)(g1-g18). Rotor of the motor constructed with the squirrel cage winding to avoid internal locking between stator and rotor [8-11]. 


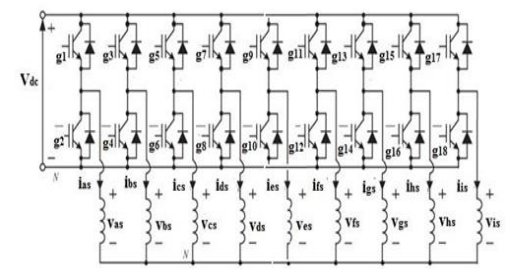

Fig.2. Topology of Nine Phase Induction Motor fed by VSI

Nine Phase Induction Motor designed with specifications shown in table 1:

Table 1. Specifications of Nine Phase Induction Motor

\begin{tabular}{|l|l|}
\hline Motor & Induction Motor \\
\hline Rotor Type & Squirrel cage \\
\hline Supply & 9 phase \\
\hline Rated Voltage & $230 \mathrm{~V}$ \\
\hline Rated Frequency & $50 \mathrm{~Hz}$ \\
\hline $\mathrm{Hp}$ & $2 \mathrm{hp}$ \\
\hline pole & 2 pole \\
\hline speed & $3000 \mathrm{rpm}$ \\
\hline class & $\mathrm{F}$ \\
\hline connection & star \\
\hline Output power & $1.5 \mathrm{kw}$ \\
\hline
\end{tabular}

\section{MODELING OF NINE PHASE VSI}

As shown in Fig.3. modelling od nine phase inverter consists of nine legs and eighteen semiconductor switches (MOSFT's/IGBT's) connected in series to run nine phase induction motor. Nine phase VSI is energized by DC power supply to control switches $\left(\mathbf{V}_{\mathrm{A}}-\mathbf{V}_{\mathbf{I}}\right)$ to drive nine phase induction motor $\left(\mathbf{e}_{\mathbf{a}}-\mathbf{e}_{\mathbf{i}}\right)$. Nine legs are $(360 / 9) 40^{\circ}$ out of phase with other and each leg has two switches conduct for the period of $180^{\circ}$. All switches triggered by PWM signals[12-13].

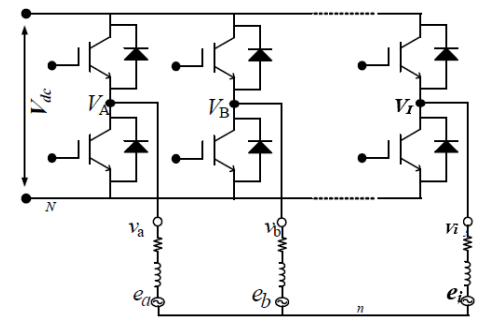

Fig.3. Topology of Nine Phase VSI
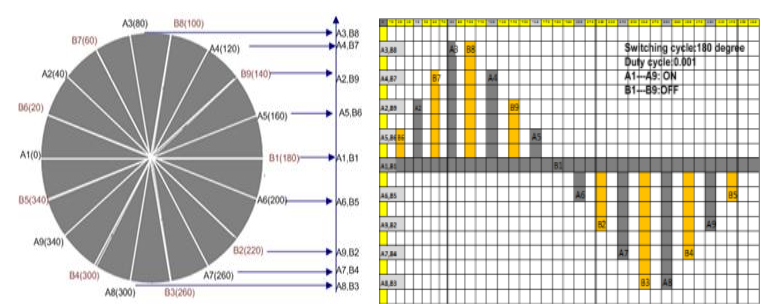

Fig.4. Switching Cycle of Inverter legs with $40^{\circ}$ phase shift and $180^{\circ}$ conduction

Load voltage of VA to VI can be easily found as shown in equation (2) and (3) where ' $\mathrm{V}_{\mathrm{nN}}$ ' is phase to neutral voltage.

$$
\begin{aligned}
& \mathrm{V}_{\mathrm{A}}=\mathrm{V}_{\mathrm{a}}+\mathrm{V}_{\mathrm{nN}} \\
& \mathrm{V}_{\mathrm{I}}=\mathrm{V}_{\mathrm{i}}+\mathrm{V}_{\mathrm{nN}} \\
& \mathrm{V}_{\mathrm{nN}}=(1 / 9)\left(\mathrm{V}_{\mathrm{A}}+\mathrm{V}_{\mathrm{B}}+\ldots \ldots \ldots \ldots \ldots \ldots \ldots \ldots \ldots \ldots \ldots\right. \\
& \mathrm{V}
\end{aligned}
$$

IV. THERMAL MODEL

Thermal modelling of the motor is developed according the principle of Kessler. According to the principle Kyander the high of accuracy can be achieved by modest subdivision in geometrical parts of machine. Various body parts of motor can be identified as a node in the thermal network. The heat source, thermal capacitance and thermal resistance are associate as node with each other [14-15].

The thermal model of three nodes, three resistance and capacitance are as shown in Fig.5. The corresponding thermal network formed in between nodes capacitance and resistance.

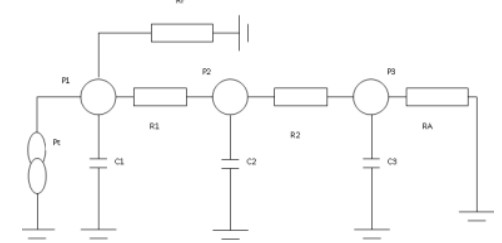

Fig.5: Thermal model of an induction motor

Where $\mathrm{P}_{1}, \mathrm{P}_{2}, \mathrm{P}_{3}$ represents heat generation at stator, frame and at body respectively. ' $\mathrm{R} 1$ ' is thermal resistance between stator and frame $\left(R_{s f}\right),{ }^{\prime} \mathrm{R}_{2}$, is thermal resistance between frame and body $\left(R_{f b}\right)$ and ' $\mathrm{R}_{3}$ ' is thermal resistance between body and ambient $\left(R_{b a}\right)$. The equations for transient state thermal model of induction motor is as follows(3),(4),(5);

$$
\begin{aligned}
& \mathrm{P} 1 \text { (stator) }=\mathrm{C} 1 \frac{\mathrm{dt}}{\mathrm{dx}}+\frac{\text { Tstator-Tframe }}{\mathrm{Rsf}}+\frac{\text { Tstator-Tambient }}{\mathrm{Rsa}} \\
& \mathrm{P} 2(\text { frame })=\mathrm{C} 2 \frac{\mathrm{dt}}{\mathrm{dx}}+\frac{\text { Tframe-Tstator }}{\mathrm{Rsf}}+\frac{\text { Tstator-Tbody }}{\text { Rsb }} \\
& \mathrm{P} 3 \text { (body) }=\mathrm{C} 3 \frac{\mathrm{dt}}{\mathrm{dx}}+\frac{\text { Tbody-Tframe }}{\mathrm{Rbf}}+\frac{\text { Tbody-Tambient }}{\text { Rba }}
\end{aligned}
$$

\section{METHODOLOGY FOR THE DESIGN OF NINE PHASE INDUCTION MOTOR}

The methodology for the illustration of nine phase induction motor is shows as a block diagram in Fig.6. The Ac power supply of $230 \mathrm{v}$ converted to $12 \mathrm{v}$ Ac supply by using step down autotransformer. Bridge rectifier converts AC to DC $12 \mathrm{v}$ supply. Eighteen control signals are generated using controller IC(AT89S52) and fed to MOSFET's of nine phase inverters through driver circuit. The generated control signals used to run nine phase induction motor with no load and load condition. J type thermocouples inserted to the various parts of the motor and connected to the temperature module kit, the module kit interfaced to personnel computer where the experimental data has been collected and used to draw the graphical analysis. The results are monitor with power Analyzer to study various parameters of nine phase induction motor. The complete experimental setup for the data analysis is as shown in Fig.7. 


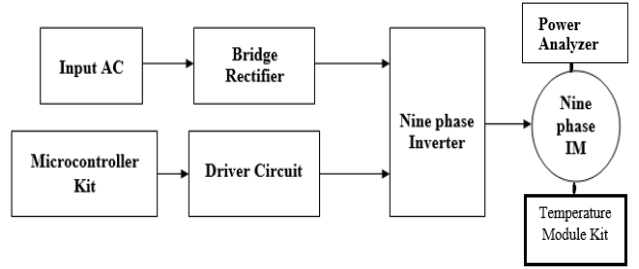

Fig.6. Block diagram of complete experimental setup

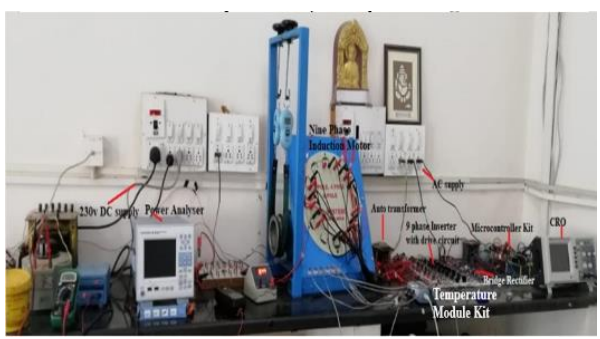

Fig.7. Experimental setup of Nine Phase Induction Motor Drive

\section{RESULTS AND DISCUSSIONS}

The temperature analysis Nine Phase Induction has been constructed experimentally and studied for a frequency of $10 \mathrm{~Hz}$ and $46 \mathrm{~V}$ The harmonics and THD is obtained using Power Analyzer. Experimental results are monitored, studied and compared with theoretical data. Fig.8. (a) (b) shows the line to neutral voltage and current waveforms and various parameters (Voltage, Current, Power, THD) respectively. The temperature of Nine Phase Induction motor at various part is as shown in the table2. Fig.9. (a) (b)and (c) shows the experimental graphical representation of temperature data at various parts of the nine phase induction motor with respect to time period of $4 \mathrm{hrs}$ with no load and with load $(600 \mathrm{gm})$.

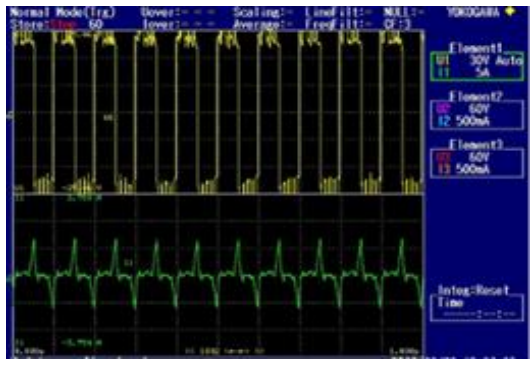

(a)

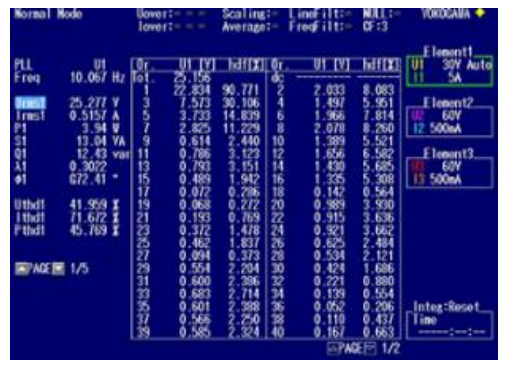

(b)

Fig.8. Power Analyzer results (a) Line to neutral voltage and current waveform (b) parameters results of Nine Phase Induction Motor Drive (10 $\mathrm{Hz})$
Table.2. Comparison of temperature at different load for various parts of nine phase induction motor

\begin{tabular}{|l|l|c|c|c|}
\hline Motor & \multicolumn{4}{|c|}{ Temperature $\left({ }^{\circ} \mathrm{C}\right)$ at different load } \\
\hline $\begin{array}{l}\text { Body } \\
\text { Parts }\end{array}$ & $\begin{array}{l}\text { gm } \\
\text { gearing1 }\end{array}$ & $\begin{array}{l}200 \\
\text { gm }\end{array}$ & $\begin{array}{l}400 \\
\text { gm }\end{array}$ & $\begin{array}{l}600 \\
\text { gm }\end{array}$ \\
\hline Bearing2 & 38.22 & 45.57 & 46.56 & 48.42 \\
\hline $\begin{array}{l}\text { Stator } \\
\text { winding1 }\end{array}$ & 42.42 & 40.92 & 41.79 & 44.57 \\
\hline $\begin{array}{l}\text { Stator } \\
\text { winding2 }\end{array}$ & 40.38 & 42.28 & 43.30 & 48.07 \\
\hline Frame & 39.45 & 41.50 & 42.50 & 45.51 \\
\hline Body & 40.04 & 42.06 & 42.97 & 45.73 \\
\hline $\begin{array}{l}\text { Room } \\
\text { Temp }\end{array}$ & 28.75 & 31.44 & 31.47 & 27.96 \\
\hline
\end{tabular}

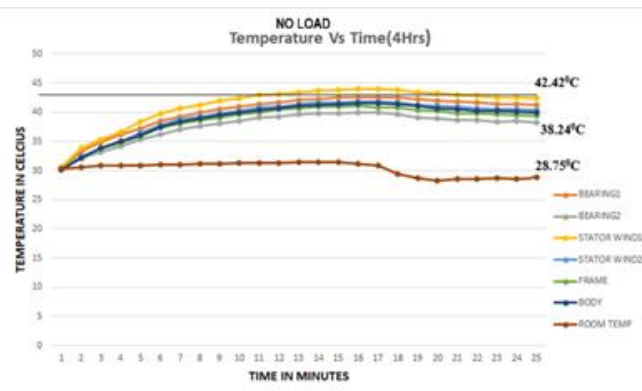

(a)

LOAD(600gm)

TEMPERATURE Vs TIME(4Hrs)

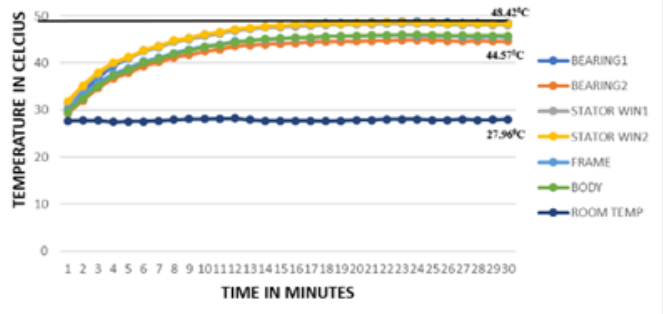

(b)

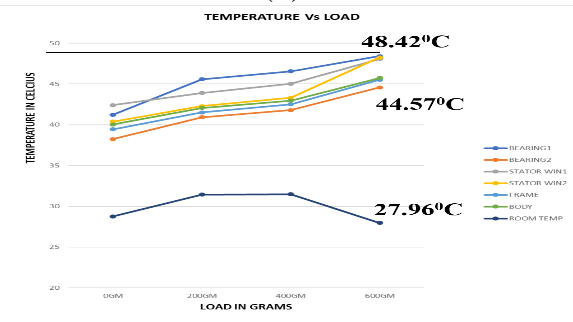

(c)

Fig.9. Temperature Analysis with (a) no-load (b) load(600gm) (c) variable load condition $(10 \mathrm{~Hz})$

\section{CONCLUSION}

Data analysis of nine phase induction motor with PWM voltage source inverter has been done experimentally for various loads. It is concluded from the experimental results that the rate of rise of temperature at various parts of nine phase induction motor with various load is found to be increased with variation of load condition. The experimental work is to be extended to study the thermal model of nine phase induction motor with various modulating techniques. 


\section{REFERENCES}

[1] Rashid M. H. "Power Electronics Circuits Devices and Applications",PHI $3^{\text {rd }}$ edition, 2004, New Delhi.

[2] Bhimbra P. S, “ Power Electronics “,Khanna Publications,4rth edition”, 2003, New Delhi.

[3] Gopal K. Dubey, "Fundamentals of Electrical Drives", 2nd Edition, Narosa Publishing House, New Delhi, 2011.

[4] B. K. Bose, Ed., Power Electronics and Variable Frequency Drives.New York: IEEE Press, 1996.

[5] B. Bose, power Electronics and AC drives Englewood cliffs, N prentice Hall, 1986.

[6] Maswood. Ali.I \& Al-Ammar. Essam "Analysis of a PWM Voltage Source Inverter with PI Controller under Non-ideal conditions" International Power Engineering Conference-IPEC,2010.

[7] M. Jones and E. Levi, "A literature survey of state-of-the-art in multiphase ac drives", in Proc. 37th Int. UPEC, Stafford, U.K., 2002, pp. 505-510.

[8] "IEEE Standard Test Procedure for Polyphase Induction Motors and Generators", volume 112, issue 1996 of IEEE, by IEEE Power Engineering Society.
[9] G.K.Singh, "Multi phase Induction Machine Drive research survey,'Elect power syst. Res, vol62,pp 139-147,2002

[10] E. Levi, R. Bojoi, F. Profumo, H. A. Toliyat, and S. Williamson, "Multiphase induction motor drives-A technology status review", IET Elect. Power Appl., vol. 1, no. 4, pp. 489-516, Jul. 2007.

[11] E. Levi, "Multi-phase machines for variable speed applications,", EEE Trans. Ind. Electron., vol. 55, no. 5, pp.1893-1909, May 2008.

[12] K. P. Prasad Rao, B. Krishna Veni, D. Ravithej, "FIVE-LEG INVERTER for FIVE-PHASE SUPPLY", International Journal of Engineering Trends and Technology- Volume3Issue2- 2012.

[13] "Five-Phase Induction Motor Drive System Fed from Five-Phase Matrix-Converter", Proceedings of the IEEE 15th International Middle East Power Systems Conference (MEPCON'12), Alexandria University, Egypt, December 23-25, 2012, Paper ID 302, pp 898-903.

[14] Kessler,A. Versucheinergenaueren Vorausberechnungdes zeitlichen Erwarmungsverlaufes $\quad$ Elektrischer Maschinenmittels Warmequellennetzen. Archiv Fur Elektrotechnik, vol.45,no.1, pp.5976, 1960.

[15] Kylander, G. Thermal modeling of small cage induction motors. Doctor of Technology Thesis, Chalmers University of Technology, Gothenburg, Sweden,1995. 